\title{
Culture and Accounting Practices in Indonesia
}

\author{
Jhon Urasti Blesia ${ }^{1 *}$ \\ ${ }^{1}$ Faculty of Economic and Business, Cenderawasih University, West Papua, Indonesia.
}

Author's contribution

The sole author designed, analyzed and interpreted and prepared the manuscript.

Article Information

DOI: $10.9734 / A J E B A / 2017 / 36846$

Editor(s):

(1) Chen Zhan-Ming, School of Economics, Renmin University of China, China.

Reviewers:

(1) O. Ademola Abimbola, Ladoke Akintola University, Nigeria.

(2) Elżbieta Szczepankiewicz, Poznan University of Economics and Business, Poland. Complete Peer review History: http://www.sciencedomain.org/review-history/21398

Mini-review Article

Received $19^{\text {th }}$ September 2017

Accepted $10^{\text {th }}$ October 2017

Published $13^{\text {th }}$ October 2017

\begin{abstract}
This article discusses the cultural impacts on the accounting values and practices in the context of Indonesia. Hofstede's cultural dimensions (individualism versus collectivism, large versus small power distance, strong versus weak uncertainty avoidance and masculinity versus femininity) with Gray's accounting values (professionalism versus statutory control, uniformity versus flexibility, conservatism versus optimism and secrecy versus transparency) are applied to Indonesia's accounting systems and practices. The presented article showed that there has been small progress in enabling auditors or accountants to exercise their individual professional judgments. As a result of the capitalist system, with its heavy government intervention in the practices of the accounting profession, the professionalism in the accounting sector is still weak. This in turn influences the disclosure of accounting information. Indonesia's collectivistically-oriented society thus has caused a lower level of professionalism where management, including accountants and auditors of the firms, find it difficult to exercise their professional judgments. This then has a direct impact on the uniformity of accounting practices as well as on the disclosure of accounting information. The strong avoidance of uncertainty in Indonesia results in the conservatism of accounting practices, where the use of the historical cost of asset valuation, recognition of internally-generated assets and amortization of those intangible assets are largely practised. There is a strongly masculine influence in the society, which causes secrecy, thus restricts the disclosure of accounting information with the intent of avoiding competition among the society.
\end{abstract}

*Corresponding author: E-mail: jhon.blesia@pg.canterbury.ac.nz, jhoe_bless@yahoo.com; 
Keywords: Cultural dimensions; accounting values and practice; enforcement; measurement; information disclosure.

\section{INTRODUCTION}

The issues of cultural influence on the accounting practices in different countries have been intensively studied by many researchers $[1,2,3,4,5,6,7,8]$. It has been shown through many empirical analyses, case studies and much academic literature, that accounting values evolve to suit the circumstances of a particular society with its own, unique cultural values at a particular time [1,2,9]. Gray [10] pointed out that accounting is influenced by societal values affected by ecological influences through geographic, historical, technological and urbanization factors. These in turn are affected by external factors, such as; the force of nature; trade; investment and conquest. The significance of cultural dimensions thus correlates strongly with accounting values, and this in turn influences the development of accounting practices in different countries.

By applying the Hofstede's model of unique societal values [6] and Gray's extended model of cultural values, to accounting values [4], this article will discuss how culture can affect accounting values and practices in Indonesia. This article will briefly explain societal values developed by Hofstede; then it will examine the extended model of cultural dimensions in relation to accounting values constructed by Gray. With a particular emphasis on linking both Hofstede and Gray's models to accounting values and practices; this article then constructs some discussion to finally justify accounting values and practices in Indonesia. The benefits of this article are to gain a deep understanding of Indonesian culture as it responds to the impact of the accounting values and practices we use today.

\section{HOFSTEDE'S SOCIETAL AND GRAY'S ACCOUNTING VALUES}

Hofstede [6] defined culture as "a collective programming process by a society which distinguishes the belief systems of its members from other societies". Culture is characterised by specification of such aspects as symbols, heroes, rituals and values; and Hofstede argued that the value is the most difficult aspect to change. Culture is also considered as an essential element in our understanding of social system changes, such as the norms and values of the systems, the behaviour of the groups and their interaction across systems [11,4]. Hofstede's cultural study representing the most extensive research on cultural differences in various countries [12,2,3] consists of four underlying societal values which can be held by each country. These four dimensions are individualism versus collectivism; large versus small power distance; strong versus weak uncertainty avoidance and masculinity versus femininity.

Based on extensive cultural studies, as well as subsequent statistical analysis of four dimensions of culture or common social preferences constructed by Hofstede, different societies can then be separated from one another; and these constructs can also be used to predict and explain ex-post institutional structures and behaviour at a societal level [7]. Hofstede's four cultural dimensions are expressed as follows;

Individualism versus Collectivism: Individualism refers to a loosely-knit social framework where individualism in the society means individuals are supposed to take care of themselves and their immediate family only. Collectivism, on the other hand, stands for a tightly-knit social framework in which individuals can expect their relatives, clan, or other in-groups to look after them in exchange for unquestioning loyalty. Individualism is defined as a relationship of members of a given society to their family, where more individualistic cultures accentuate the interest of the self and immediate family, whereas collectivism emphasizes that of broader social groups. This study addresses, as fundamental issues, the degree of interdependence a society maintains among individuals.

Large versus Small Power Distance: Power Distance depends upon the extent to which the society generally accepts that power is unequally distributed within its institutions. In the greater power distance, society accepts a hierarchical order where everybody has a place which needs no further justification; in small power distance, in contrast, people in a society strive for power equalisation and demand justification for power inequalities. The fundamental issue addressed by this dimension is the way in which a society handles inequalities when they occur among its people. 
Strong versus Weak Uncertainty Avoidance: Uncertainty Avoidance is measured by the degree to which ambiguity and uncertainty is tolerated. This feeling then leads society to beliefs promising certainty, and to maintaining institutions that protect conformity. A society with strong uncertainty avoidance tends to maintain rigid codes of belief and behaviour and is intolerant towards deviant persons and ideas. The tendency of a society with weak uncertainty avoidance, on the other hand, is more relaxed, where practices count more than principles; in such a society, the deviances are more easily tolerated. The fundamental issue in addressing this dimension is the ways in which a society reacts to the fact that time only runs one way and the future is still unknown; whether it tries to control the future or to let it happen.

Masculinity versus Femininity: Masculinity and Femininity reflect differentiated sex roles where a society with masculinity holds a preference for achievement, heroism, assertiveness, and material success. Its opposite, a society with femininity views, stands for a preference for relationships, modesty, caring for the weak, and the quality of life. The fundamental issue addressed by this dimension is the extent to which a society allocates social (as opposed to biological) roles to the sexes.

Gray then extended Hofstede's societal values and linked them to accounting values [4]. Gray's model of the cultural dimensions within societal values in relation to accounting values and practices began with Hofstede's preposition that societal values have institutional consequences in the forms of legal, political and economic systems that include the pattern of corporate ownership and capital markets. Gray's extended model of societal values to accounting values demonstrates that, in turn, they influence the structures and practices of accounting, including measurement, recognition and disclosure in financial reporting $[13,7]$. Gray constructed four measurable accounting values which can be used to justify a country's accounting culture; namely professionalism versus statutory control; uniformity versus flexibility; conservatism versus optimism and secrecy versus transparency.

Examining, first, professionalism versus statutory control; professionalism refers to the preference for an exercise of professional judgements rather than those of an individual, and it emphasises the maintenance of professional self-regulation. Statutory control refers to the compliance to legal requirements. Here, accountants are required to use their independent attitudes and exercise their individual professional judgments to a greater extent in running accounting practices in their firms. However, accountants subject to their professional issues are also subject to public regulation and statutory control. Cultural dimensions, nevertheless, can influence whether accountants focus more on professionalism or on statutory control.

The second aspect to be examined is uniformity versus flexibility, where uniformity prefers the enforcement of uniform accounting practices between companies and maintains the consistent use of such practices over time. The concept of uniformity demands very strict practices, the maintenance of consistency within companies over time, and most of the time it refuses any different interpretations. Flexibility, on the other hand, prefers to yield more to persuasion in applying accounting practices in accordance with the perceived circumstances of individual companies. Flexibility is thus open to different interpretations and allows a moulding of accounting practices to suit the circumstances of individual companies.

Next to be considered is conservatism versus optimism; conservatism refers to the preference for a cautious approach to measurement so as to cope with the uncertainty of future events. Optimism, in contrast, constitutes a more optimistic, laissez-faire, risk-taking approach. Conservatism or the concept of prudence for asset measurements and the reporting of profits is largely practised by accountants throughout the world, it varies according to individual countries and is practised differently in different places, for example, continental European countries with stronger conservative approaches, such as France and Germany, differ when compared with lesser conservative attitudes held by such as the United Kingdom, the United States and New Zealand.

And the last aspect to be considered is secrecy versus transparency, where secrecy refers to confidentiality and the restriction of information disclosure about the business only to those who are closely involved with its management and financing. Secrecy will also be closely related to the concept of conservatism, where both values imply a cautious approach to corporate financial reporting in general. This is opposed to transparency, in which the disclosure of information is more transparent, open and 
publicly accountable. In accounting information, the concept of transparency means that the disclosure of accounting information is freely published in order to show accountability [14].

\section{THE RELATIONSHIP BETWEEN HOFSTEDE'S CULTURAL DIMEN- SIONS AND GRAY'S ACCOUNTING VALUES AND PRACTICES}

Gray used Hofstede's societal value model to explain specifically the effect of those values on the accounting values and practices constructed above. An important point here is that Gray converted Hofstede's cultural and societal values into accounting values and posited the relationship between both values. It is given that Gray's model proposed that accounting policy decisions at a national level are influenced by cultural values as constructed by Hofstede. Table 1 summarizes the relationships between Gray's accounting model and Hofstede's societal values. Gray noted that specific societal dimensions in relation to accounting values and practice then influence accounting's measurement and disclosure in financial reporting. Fig. 1 shows the relation of Hofstede's societal values with Gray's accounting values and the specific areas of accounting practices associated with measurement and disclosure. This model is reproduced by Radenbaugh \& Gray [15].

Gray, in order to connect Hofstede's societal values and his accounting values, argued that a society emphasising a high level of individualism will give greater chances for individual professional judgements and thus, he reasoned, this will influence professional accounting bodies. $\mathrm{He}$ added that high individualism implies a suspicion of uniform and secretive disclosure practices as well as conservative calculations. Professionalism is also more likely to be accepted in the lower levels of power distance than in that of higher levels. In the lower power distance society, the society considers rights to be equal where people at various lower levels easily trust other people and feel less threatened with what is going to happen in the society. Individual professional judgments, furthermore, will be easily applied where there is a stronger level of uncertainty avoidance in the society.

Uncertainty avoidance in a society is linked to uniformity or flexibility, given that a society with stronger uncertainty avoidance will be more concerned with law and order and rigid codes of behaviour. A stronger level of uncertainty avoidance in a society needs written rules and

Table 1. The relationship between Gray's accounting dimension and Hofstede's cultural dimensions

\begin{tabular}{lllll}
\hline & Professionalism & Uniformity & Conservatism & Secrecy \\
\hline Power distance & - & + & $?$ & + \\
Uncertainty avoidance & - & + & + & + \\
Individualism & + & - & - & - \\
Masculinity & $?$ & $?$ & - & - \\
\hline \multicolumn{2}{l}{ Notes: "+" indicates a direct relationship between relevant variables, "-inverse relationship and "?" indicates that }
\end{tabular}

\begin{tabular}{|c|c|c|}
\hline Societal Values & Accounting Values & $\begin{array}{l}\text { Accounting } \\
\text { System/Practices }\end{array}$ \\
\hline Individualism/Collectivism & Professionalism & Authority/Enforcement \\
\hline Power Distance & Uniformity/Flexibility & \\
\hline Uncertainty Avoidance & Conservatism/Optimism & $\begin{array}{l}\text { Measurement of Asset } \\
\text { and Profit }\end{array}$ \\
\hline Masculinity/Femininity & Secrecy/Transparency & Information Disclosure \\
\hline
\end{tabular}

Fig. 1. Hofstede's societal values, Gray's accounting dimension, measurement and disclosure Source: (Radebaugh and Gray, 1993) 
regulations in respect to conformity and the search for ultimate truth and values. There is also a link between uniformity and power distance, where uniformity is more easily facilitated in a society with a greater power distance. This will give significant input to accounting values as the concepts of uniformity, consistency and comparability are incorporated into the fundamental features of accounting principles world-wide.

Stronger uncertainty avoidance is also closely linked to the concept of conservatism, given that there is a concern for security and a perceived need for the adoption of a cautious approach in coping with the uncertainty of future events. A preference for a more conservative measure of profit will be consistent with stronger uncertainty avoidance. There might or might not be a link between a higher level of individualism and masculinity on the one hand and a lower level of uncertainty avoidance on the other hand, leading to an emphasis on individual achievement and performance where these are likely to foster a less conservative measurement.

Uncertainty avoidance, power distance and individualism can also be linked to secrecy or confidentiality of information. There is a very close relationship between uncertainty avoidance and the secrecy of information where there is a need to restrict information in order to avoid conflict and competition and to maintain security. Higher power distance is also closely linked to secrecy where a society with a higher power distance is likely to restrict information disclosure in the effort to preserve power inequalities. The other close link is between collectivist society and the disclosure of information, where society will disclose information to those close or involved in their firms. Masculinity as opposed to femininity is also closely linked to the disclosure of information. A society which values masculinity will focus more on achievement, heroism and assertiveness and will be less likely to be open to the information, especially socially related information.

It must be admitted that the Hofstede - Gray model has been intensively criticized due to its weakness of quantitative measures, and it requires further research [16]. Another weakness indicated by Gray is that the relative force of accounting values indicated in the model, and institutional consequences, will vary from country to country in their impact on the final form of any accounting system. However, empirical tests have been continuously conducted to examine the validity of the Hofstede - Gray framework. Despite the lack of evidence of any relationship between societal dimensions and accounting values $[17,18,19]$, a number of findings support Hofstede and Gray's hypothesis, showing significant correlations between the influence of culture and accounting values $[20,7,8,21]$. Based on these significant correlations, the cultural dimensions and accounting practices in Indonesia are thoroughly discussed here.

\section{OVERVIEW OF ACCOUNTING ECOLOGY IN INDONESIA}

This section overviews the accounting scene in Indonesia from an ecological perspective, highlighting some important factors and their impacts on accounting values and practices in Indonesia.

Indonesia, one of the South East Asian countries, is the largest archipelago in the world. With almost 210 million people and at least 300 distinct ethnicities with unique cultures and customs, Indonesia is recognized as having the fourth largest population, with the biggest Muslim population in the world. Most groups speak various indigenous languages, however, "Bahasa Indonesia" is largely used as a national language to link the groups. Indonesia has a capitalist economic system with significant government involvement; it is called "crony capitalism". During the Suharto era, Indonesia's economy experienced major reforms of capital investments (foreign and domestic), taxation systems, bank and financial service. Through these changes Indonesia opened up many industries, allowing foreign investors to have $100 \%$ ownership in certain areas [22]. Indonesia politically is a large power distance society where the government's influence is apparent in many political aspects [6]. The aspects of political behaviours in Indonesia follow the roots of political culture from its pre-colonial Javanese kingdom where central government is essentially an extension of the ruler's personal household and staff. There have been attempts at decentralisation during the post-Suharto era, such as Law No, 22/1999, pertaining to local government and Law No. 25/1999, pertaining to fiscal decentralization. Indonesia, however, continues to have a large power distance and people tend to accept an unequal power distribution within organizations and institutions. The legal system is based on Roman-Dutch law, but tradition and customary laws and Syariah (Sharia) or Islamic law are the 
main resources of the various legal orders $[23,22]$.

Indonesia's organizational environment allows joint ventures, based on the principle of "gotong royong". Indonesia prioritizes the spirit of togetherness and highlights the concept of "musyawarah" in all avenues of the life of its people. In the concept of musyawarah all points of view regarding any issues and problems must be firstly discussed and decided together. The organizational environment in Indonesia, however, relies upon a mechanism in which the ruler governs, and the principle in which capital resources held by domestic companies largely come from banks, and there is no pressure for the companies to publish audited financial statements $[24,25]$. In the professional environment, political conflicts have a significant, direct impact on the professional activities of the society. As a result of political influences and corruption, economics and commerce along with their associated legality and accounting processes - lost their prominence $[22,8]$.

Diga and Yunus [23] made an important point regarding the history of the accounting profession in Indonesia. The professional community is closely linked to the colonial past when no Indonesians were involved in influential positions or professions, such as law and accountancy. After 10 years of independence, Accountancy Law was enacted where graduate accounting students from the state university were allowed to have the title "Accountant". Dutch custom, on the other hand, still dominated and ensured that no Indonesian accountants could practice audit or sign audit reports. The Indonesian Accounting Institute or IAI (Ikatan Akuntan Indonesia) was then established in 1957; four membership categories were then formed and all need to be registered with the Ministry of Finance.

Indonesia's accounting environment follows US accounting concepts. The Soeharto era led to an increase of US influence in all areas of business, including accounting. Together with the support given by the US to education in Indonesia namely Ford Foundation grants - US accounting was transferred to Indonesia through multinational corporations, international accounting firms and the replacement of Dutch texts by American textbooks at the universities. A code of ethics applied to public accountants, relating to attitude, independence, professional skills, responsibilities to clients and other professional accountants were introduced in
1987. Within this, all principles and standards were primarily taken from the US statements of accounting standards [22].

\section{ANALYSIS AND DISCUSSION OF CULTURAL INFLUENCE ON INDONESIA'S ACCOUNTING PRACTICES}

Indonesian culture in general has been shifted from the conglomeration to the reformation era. Indonesia's political crisis has enormously affected the economy, followed by the financial pressures since the reformation era in 1994 [26]. This fact has also had a serious impact in shifting societal values which ultimately influenced accounting values and practices.

Hofstede suggested that Indonesia is a large power distance and collectivist country, this assessment being based on the rankings of cultural values of power distance and individualism where Indonesia's power distance stands at 43-44 and individualism at 6-7 out of 50 countries [6]. Due to the country's higher power distance, the chances for accountants to exercise their individual professional judgments in Indonesia are very low. Subiyantoro and Hatane [27] on the other hand, argued that, in the reformation era of 1994, there has been a small improvement in the power distance society. Since then, a higher level of management has mostly begun to discuss and address a company's main issues with the lower level. When making final decisions; top management is expected to use its authority and position in its personal interests. Thus, in running attested and non-attested services, accountants or auditors have started to freely express their individual professional judgments. Nevertheless, as a result of the use of a capitalist system with heavy government intervention [28], the influence of government determines the stages of Indonesia's accounting profession. The professionals as a result are likely to be weak; rules and procedures they follow tend to lose meaning and impact. Although the power gap in Indonesia since the reformation period has been continually diminished in business and society, the leadership and decision-making process frequently use the bottom-up model involving middle and lower staff [27] but, due to government intervention, the level of professionalism in the Indonesian accounting profession is still low. 
Indonesia's power distance has a direct impact on the secrecy or confidentiality of accounting information disclosures. The creation of national wealth involves both foreign and domestic capital participation; the fact that it still heavily depends on the government's initiative has caused lack of competition among firms, affecting their ability to attract funding from the capital market. A few firms that are established and well-connected to government groups can successfully publish their disclosure of operating results and asset performance to attract markets, and as a result, other firms are no longer concerned about financial information disclosure. Those firms, in other words, are not willing to provide information about their success and performance in order to attract investors and other stakeholders. Nevertheless, the situation will be different when the needs of the capital market for the additional sources increase, and when those wellconnected to government groups cannot fulfil it sufficiently. The competition among firms will then start to heat up, and thus the financial reports used as a medium to present financial and non-financial information will lead the firms. Most of them will then choose aggressive accounting policies [8]. This is where the disclosure of information from both wellconnected and the other less well-connected government groups will be clearly seen and publicly opened.

In individualism versus collectivism, each level of the community in the hierarchy of Indonesian society is more collectivistically-oriented $[29,30]$. This behaviour is seen in all parts of society [31, 30]. Indonesian accounting students studying in overseas universities also show this behaviour [32]. However, in today's society, the magnitude of the welfare demands of the crowd and the accomplishment of the groups have led individuals to think of themselves and to pursue their goals more forcefully [27], the collectivism in society is still dominant. Gray, [4] as cited in Sudarwan and Fogarty [8], argued that this orientation has negative impact on professionalism in accounting practices. In such an environment, most managers of firms, in fact, are pressured to exercise their individual professional judgments and skills in many cases. This could also include the professionalism needed in the preparation and presentation of financial statements.

Consistent with the hypothesis developed by Sudarwan \& Fogarty, individualism in business firms is also significantly, but negatively, correlated to the uniformity of Indonesia's accounting practices [8]. Managers are forced to exercise their individual professional judgments when there is an increase in capital needs and in their firms' participation in the market. In this condition, managers need to possess creativity and initiative to be flexible in adapting and adjusting to the business changes. This, however, creates more complexity throughout a firms' operation and reporting practices. Lower level of individualism in the society; the immature accounting profession, in guiding accountants in applying their individual professional judgements and in accommodating the complexities of operation and reporting practices, have not been either able or flexible to the business changes [33].

Inappropriate accounting standards in Indonesia have also caused many discrepancies among the reporting practices, all leading to uniformity in accounting processes.

Indonesian collectivistic society also has a direct impact on the disclosure of accounting information. Parera and Baydoun [22] noted that society prioritizes the spirit of togetherness in the decision-making process. Radebaugh and Gray [15], however, argued that collectivistic society tends to disclose information only to those close to or involved in their group. Due to the predominance of credit as a resource of finance in Indonesia (called the "credit insider system"), and to the fact that the main providers of capital have direct access to the financial or nonfinancial information from the companies, there is no pressure from the capital market upon companies in Indonesia to publish audited financial statements [25]. This situation is likely to change if the main providers of finance come from equity-outsiders or investors where audited financial statements are required.

Society in Indonesia has higher uncertainty avoidance than in other countries. This is evidenced by the greater demands, requirements and detailed instructions about what is required from individuals in society. Because of the high intensity of stress and anxiety regarding uncertainty and risk, and the intense degree of implementation in legislation, laws and regulations also indicate high uncertainty avoidance in Indonesia. The power of religion Islam - also plays a potential part in affecting detailed rules and instructions in the structure of society $[34,35]$. One of Sudarwan \& Fogarty's hypotheses found a positive and significant 
correlation between uncertainty avoidance and conservatism of accounting practices in Indonesia. Business and economic activities have led the government to lessen its control over the country's economics through the deregulation policy where firms are forced to deal with an increasing market [36]. In a conservative approach, firms can pass their investment opportunities to others and this affects their product performance and financial markets.

Stronger uncertainty avoidance and the impact on the conservative approach of accounting practices in Indonesia is evidenced in the use of historical cost as a common approach for asset valuation. The reasons the historical cost approach is used largely for value assets are; firstly, it provides accurate information about the past and has the ability to predict the future's performances; secondly, it is based on actual and not merely possible transactions and under this cost, actual transactions are recorded. The higher uncertainty avoidance society in Indonesia has a direct impact on the choice of historical cost, since this approach can provide a certain amount of asset valuation of the companies. Although it is admitted that determining the cost is not a straightforward exercise where most of them need professional judgments and estimation from accountants that includes capitalising or expensing decisions about the cost, Indonesia has chosen to avoid an uncertain future by following a historical cost approach.

The amortisation policies in Indonesia, due to the adoption of a conservative approach, are real examples resulting from the higher level of uncertainty avoidance society. Goodwill acquired in a business combination, for example, is impaired instead of being amortized. International Accounting Standard (IAS) 36, on the other hand, requires goodwill acquired in a business combination to be tested for impairment as part of impairment testing the cash-generating unit(s) to which it relates. IAS 36 also requires goodwill for an annual impairment test to be performed at any time during an annual reporting period for a cash-generating unit (group of units) to which goodwill has been allocated, provided the test is performed at the same time every year. On account of the conservative approach, Indonesia's Financial Accounting Standards 22 section 39 shows that goodwill as a result of business combination must still be amortized and allocated according to systematic estimates of the duration of the assets. Goodwill in general has a cycle of not more than 20 years, so goodwill therefore must be amortized not more than 20 years and can be started once the asset is ready to use.

Stronger uncertainty avoidance is also positively correlated to the secrecy in Indonesia's accounting practices. As the government relies heavily on guidelines for certainty (as a result of the deregulation policy made and implemented by the government in order to lessen their control over the economy), many firms and the accounting profession are not ready to face this challenge [14]. This creates anxiety among them, resulting in a more secretive accounting practice. A high secrecy of accounting practices in Indonesia is furthermore influenced by the low level of individualism [8]. However, due to the currently increasing trend of firms' individualism, there has arisen a greater concern about secrecy and information disclosure.

The stronger uncertainty avoidance society in Indonesia, then, has a close link to its statutory control. Gray [4] argued that a society with a stronger level of uncertainty avoidance will need ultimate truth and values when faced to solve problems. Stronger uncertainty avoidance will force accountants or auditors to seek written rules and regulations, then to immediately apply them to fix the problems. Yunus [33] noted that Indonesia's accounting standards follow the US standards which are called "rule-based standards". The code ethic of public accountants, addressing all characteristics required by public accountants in running their accounting and auditing services, has been primarily taken from the US norms and code ethics. Due to stronger uncertainty avoidance in the society and the fact that it has a direct impact on the accounting values and practices, Parera and Baydoun [22] noted that the regulatory framework of accounting and financial reporting in Indonesia has three levels; namely presidential decrees, regulations issued by relevant government agencies, and accounting standards issued by the IAI.

In masculinity versus femininity values, Indonesia is still the domain of a classic male-gender type. Religion has also influenced this view, where men are perceived and posited at a primary position for some conservative Muslims [37]. Although most educated and skilled women have been involved in Indonesia's accounting profession, their proportion of the accounting community and profession in the conglomeration period was minimal, compared to their 
counterparts. Today's society has revealed many women involved at almost all levels of occupations and opened wider opportunities for women to pursue their professional careers. In the accounting profession, both the percentage and the treatment of women are also equally distributed.

Indonesia's stronger masculine society can be linked to the secrecy or confidentiality of information. The concept of masculinity includes focusing more on achievement and assertiveness [30], which tends to persuade people not to disclose all information to others in order to avoid competition among them. Although the concept of transparency is more disseminated to government and corporations in Indonesia, many of them still tend to keep accounting information closed from the public. Take one example; accounting issues, such as sustainability reporting are not often published by companies in Indonesia. Indonesia also has the lowest level of Corporate Social Responsibility (CSR) penetration and community development, compared with other Asian countries [38].

\section{CONCLUSION}

Various studies of cultural impacts, which have been undertaken to justify Indonesia's accounting practices are definitely true; a lower level of individualism and a high level of power distance and uncertainty avoidance have significantly influenced the higher level of conservatism and secrecy and the lower level of professionalism in Indonesia's accounting practices. It is admitted that although Indonesian firms are more adaptive to their environmental changes, influenced by the change from the conglomeration to the reformation period, both government authority and reliance of the business community on the government still play a dominant role affecting Indonesia's accounting practices.

Lack of transparency, public accountability and professionalism has caused economic problems in Indonesia as well as in other Asian countries. Regardless of whether the cultural factor is an underlying cause of this problem, what needs to be addressed is how the problems can be resolved. These issues can be solved in many ways, but in my personal opinion, a substantial degree of autonomy and independence given to the accountants in exercising their individual professional judgments is one of the ways we can minimize the problems. Accounting is also trusted to provide a vehicle to ensure transparency in the use of resources; it also could play a significant role in regaining investor confidence and in improving the relationship between providers of finance and the companies. Indonesia's economic growth is expected to play its part in strengthening the role of the accounting profession and in encouraging accountants to have independent attitudes and freely exercise their individual judgment. And as a part of maintaining their autonomy and independence, self-regulation of the accounting profession is crucial here and can be further used as a safeguard against questionable practices.

\section{COMPETING INTERESTS}

Author has declared that no competing interests exist.

\section{REFERENCES}

1. Baydoin N, Willet R. Cultural relevance of western accounting systems to developing countries.1995;31:67-92.

2. Doupnik TS, Tsakumis GT. A critical review of the tests of Gray's theory of cultural relevance and suggestions for future research. Journal of Accounting Literature. 2004;1-30.

3. Finch N. Towards an understanding of cultural influence on the international practice of accounting. Journal of International Business and Cultural Studies. 2009;1-6.

4. Gray SJ. Towards a theory of cultural influence on the development of accounting systems internationally. Abacus. 1988;33-43.

5. Gray SJ, Vint HM. The impact of culture on accounting disclosures: Some international evidence. Asia-Pacific Journal of Accounting. 1995;33-43.

6. Hofstede G. Culture's consequences: International differences in work-related values. London: Sage publication; 1980.

7. Salter SB, Niswander F. Cultural influence on the development of accounting systems internationally: A test of gray's (1988) theory. Journal of International Business Studies. 1995;379-397.

8. Sudarwan M, Fogarty TJ. Culture and accounting in indonesia: An empirical examination. The International Journal of Accounting. 1996;463-481. 
9. Hopwood A. Accounting and everyday life: An introduction. Accounting, Organizations and Society. 1994;299-301.

10. Gray SJ. Cultural influences and the international classification of accounting systems. EIASM Workshop on Accounting and Culture. 1985.

11. Harrison GL, McKinnon ML. Cultural and accounting change: A new perspective on corporate reporting regulation and accounting policy formulation. Accounting, Organizations and Society. 1986;3.

12. Askary S. Accounting professionalism - A cultural perspective of developing countries. Managerial Auditing Journal. 2006;102-111.

13. Hashim $\mathrm{H}$. The influence of culture on financial reporting quality in Malaysia. Asian Social Science. 2012;192-200.

14. Blesia Jhon Urasti, Sulelino Renny. The evaluation of major components of the corporate social responsibility in west papua's health sector. Journal of Alternative Perspectives in the Social Sciences. 2016;8(1):77-98.

15. Radebaugh LH, Gray S. International accounting and multinational enterprises. Wiley; 1993.

16. Joannidès $V$, Wickramasinghe $D$, Berland $\mathrm{N}$. Critiques on gray-hofstede's model: What impact on cross-cultural accounting research? 2012;(1-41).

17. Hope OK. Firm-level disclosures and the relative roles of culture and legal origin. 2003;14:218-248.

18. Jaggi B, Low PY. Impact of culture, market forces, and legal system on financial disclosures. The International Journal of Accounting. 2000;35:495-519.

19. Wingate ML. An examination of cultural influence on audit environments research in Accounting Regulation. 1997;1:129-148.

20. Eddie IA. Asia Pacific cultural values and accounting systems. Asia Pacific International Management Forum. 1990;16:22-30.

21. Zarzeski MT. Spontaneous harmonization effects of culture and market forces on accounting disclosure practices. Accounting Horizons. 1996;10:18-37.

22. Perera, Baydoun. Convergence with international financial reporting standards: The case of indonesia. Advances in International Accounting. 2007;20:201-224.

23. Diga J, Yunus $\mathrm{H}$. Accounting in Indonesia. Accounting in the Asia-Pacific region. 1997;282-302.
24. Blesia JU, Pramudika DR. Key aspects of the bond ratings in Indonesia. Asian Journal of Economics, Business and Accounting. 2016;1(3):1-14.

25. Hutadjulu LY, Blesia JU. Factors that affect the perception of small and medium-sized businesses (SMEs)' community on the importance of financial statements, the amount of credit received and implementation prospects. International Conference on Social Science and Biodiversity of Papua and Papua New Guinea (ICSBP 2015), Jayapura; 2016.

26. Maclntyre A. The politics of asian economic crisis, new york: Cornell university press; 1999.

27. Subiyantoro Hatane. Dampak perubahan kultur masyarakat terhadap praktik pengungkapan laporan keuangan perusahaan publik di Indonesia. Jurnal Manajemen Dan Kewirausahaan. 2007;9(1):18-29.

28. Dick $H$, Houben V, Lindblad T, Wie T. The emerge of national economy: An economic history of indonesia, 1800-2000, Australia: Allen and Unwin; 2002.

29. Mesak GBLI, Westim R, Hutajulu H, Blesia $\mathrm{J}$. Using the action research process to design entrepreneurship education at Cenderawasih University. Procedia Social and Behavioral Sciences. 2016;228:462-469.

30. Blesia Jhon Urasti, Westim, Ratang. Indigenous wisdom for developing economic life case of Yokari people, West Papua. International Journal of Indonesian Society and Culture. 2016:8(2).

31. Goldstein BL, lek M, Ratang W, Blesia J. Education and Entrepreneurship: Best Learning from Helm Project at Cenderawasih University. In International Conference on Social Science and Biodiversity of Papua and Papua New Guinea (ICSBP 2015), Jayapura; 2016.

32. Teoh HY, Serang DP, Lim C, Individualism-collectivism cultural differences affecting perceptions of unethical practices: Some evidence from australian and indonesian accounting students. Teaching Business Ethics. 1999;3(2):137-153.

33. Yunus. History of accounting in developing nations: The case of Indonesia. Tim Koordinasi Pengembangan Akuntansi, Jakarta; 1990.

34. Hadiz V. Indonesian political islam: capitalist development and the legacies of 
the Cold War. Journal of Current Southeast Asian Affairs. 2011;1:3-38.

35. Hamid S, Craig R, Clarke F. Religion: A confounding cultural element in the international harmonization of accounting? ABACUS. 1993;29(2):131-148.

36. Iqbal F, Rashid F. Deregulation and development in Indonesia. The United Stated of America: International Bank for Reconstruction and Development; 2002.
37. Hofstede G. Gender stereotypes and partner preferences of Asian women in masculine and feminine cultures. Journal of Cross-Cultural Phschology. 1996;27(5): 533-546.

38. Chapple Moon. Corporate Social Responsibility (CSR) in Asia: A Seven Country Study of CSR Website Reporting Business \& Society. 2005;44(4):415-441.

(c) 2017 Blesia; This is an Open Access article distributed under the terms of the Creative Commons Attribution License (http://creativecommons.org/licenses/by/4.0), which permits unrestricted use, distribution, and reproduction in any medium, provided the original work is properly cited.

Peer-review history:

The peer review history for this paper can be accessed here: http://sciencedomain.org/review-history/21398 